\title{
Comparative Analysis of Development of Retail and Shopping Centres After 1990 in Ljubljana and Zagreb
}

\section{Martina Jakovčić, Dejan Rebernik}

In the early 1990s, Croatia and Slovenia, along with other Central and Eastern European countries, began a process of economic transition from centrally planned to market economy. The main goal of the paper is to compare developments of new forms of retail outlets in Zagreb and Ljubljana after 1990 and to explain similarities and differences in the trend of retail development in two capital cities. The second goal is to determine the level of development of social functions of retail centres and to determine similarities and differences in the function of retail centers in Zagreb and Ljubljana.

Key words: retail, shopping centres, transition, shopping centres social function, Ljubljana, Zagreb

\section{Komparativna analiza razvoja trgovine i kupovnih centara u Ljubljani i Zagrebu nakon 1990. godine}

Početkom 1990-ih Hrvatska i Slovenija su, kao i ostale države Srednje i Istočne Europe, započele s procesom ekonomske tranzicije i prelaskom s centralno-planske na tržišnu ekonomiju. Glavni cilj ovog rada je usporediti razvoj novih oblika prodajnih prostora u Zagrebu i Ljubljani nakon 1990. te usporediti razvoj trgovine u dvama sada glavnim gradovima novonastalih država. Drugi cilj je odrediti stupanj razvoja socijalnih funkcija kupovnih centara te odrediti sličnosti i razlike $u$ funkcijama kupovnih centara $u$ Zagrebu i Ljubljani.

Ključne riječi: trgovina, trgovački centri, tranzicija, socijalne funkcije trgovačkih centara, Ljubljana, Zagreb 


\section{INTRODUCTION}

In the early 1990s, Croatia and Slovenia, along with other Central and Eastern European countries, began a process of economic transition from centrally planned to market economy. Retail was one of the economic activities in which changes were swiftest (Standl, 1998). Transition in retail includes: emergence of new retail forms, changes in location of outlets, changes in floor space, changes in the structure of products on offer and changes in ownership relations. As a result of privatization, a large number of new outlets was opened, followed by the closure of leading department stores chains. Four new retail forms have emerged: shopping centres, hypermarkets-shopping centres, hypermarkets and specialized hypermarket. Shopping center is defined as a group of retail and other commercial outlets planned and developed as consolidated unit. Hypermarket - shopping center comprises a hypermarket and several smaller retail and other commercial and service outlets in one building. A hypermarket - shopping center is owned by the retail hypermarket chain and has its name. Hypermarket is a self-service outlet with sales floor greater than $2000 \mathrm{~m}^{2}$, intended primarily for the sale of groceries and consumer goods, but can also offer other products. Specialized hypermarket is a self-service outlet with sales floor greater than $2000 \mathrm{~m}^{2}$, intended for the sale of goods for specific purposes for middle and long term provision (furniture, home, garden and technical equipment) (Lukić, Jakovčić, 2004).

This process of opening of new forms of retail outlets was accompanied by the process of internationalization, which is manifested through opening of a large number of foreign hypermarkets, shopping centers and other retail outlets. (Lukić, 2002, Pütz, 1997). The process of internationalization of retail is common for all transition countries and according to Kulke marks a second phase of transition process ${ }^{1}$. (Kulke, 1997a). The process of internationalization of retail started in Hungary, Czech Republic and Poland spreading in time to all the other countries. The reasons for a strong spread of foreign retail chains and construction of large floorspace outlets are identical in most of the transition countries: low competitiveness of fragmented domestic retail, low land prices and workforce costs, lower levels of control and undefined legislation which enables the building of large retail outlets, and growth of purchasing power. (Anić 1999; Knego, 1998). Among first retail chains who opened their retail outlets in Hungary were Metro, Obi and Baumax, while in Poland leaders were E'Leclerc, Géeant, Auchan and. Carrefoura. Strong financial background and economy of scale enables foreign companies to lower their prices (Anić, Vouk, 2000). One of first regional shopping centres in Hungary was Budagyöngye centre opened in Budapest in 1994. First hypermarket was opened by Tesco the following year and was located in Zuglo quarter in Budapest. First suburban hypermarket was Cora (French-Belgian cooperative) opened in Törökbalintu, $15 \mathrm{~km}$ southwest of Budapest (Sikos, Hoffman, 2005.). First suburban centre opened in Czech Republic was Centre Cerny Most opened in Prague in 1997 (Sykorova, Sykora 1999.). Beside western retail chain some retail chains from transition economies started the process of internationalization as well, such as the biggest Slovenian retail chain Mercator who have been opening different type of retail outlets in Croatia, Bosnia and Herzegovina and Serbia.

Foreign retail chains entered Croatian market relatively late. (Segetlija, LamzaMaronić, 1997, Anić, Vouk, 2000). The most general reason for that were unstable 
political (war and fragmented legislation) and economic situation. The most important economic reasons are high inflation and unemployment rate, a large grey market, and a weakly developed infrastructure. (Anić, Vouk. 2000, Anić 1999). In Slovenia the process of internationalization was much faster. The first foreign commercial chain Spar came to Slovenia already in 1991. In 1993 Spar opened the first hypermarket and in 2002 the largest hypermarket in Slovenia (City Park). Due to aggressive and economic successful policy of domestic commercial companies the market share of foreign commercial chains in Slovenia remained relatively low. According to research "Retail in Slovenia" (GFK - Gral Iteo, 2007), domestic company Mercator managed to maintain $44.7 \%$ market share in sales of goods for short term provision, followed by Spar/Interspar with $19.2 \%$, Tuš (domestic) with $16 \%$ and Leclerc with $1.4 \%$. Foreign commercial chains Bauhaus, Baumax and Obi have higher market shares in sales of goods for specific purposes for middle and long term provision (technical equipment, equipment for home and garden, furniture).

\section{GOALS AND METHODOLOGY}

The main goal of the paper is to compare developments of new forms of retail outlets in Zagreb and Ljubljana after 1990 and to explain similarities and differences in the trend of retail development in two capital cities. In the first part of the paper retail development in Zagreb and Ljubljana is presented. A general spatial distribution of retail and suburban shopping centers is presented as well. In the second part of the paper comparison of spatial distribution, functional structure and social functions of retail centers in Ljubljana and Zagreb is given. Several previous researches have shown that shopping centers in Zagreb and Ljubljana are still predominately places of retail therefore the intent was to determine and compare the level of development of social functions in shopping centers in those two cities.

In conducting this research different methods were used. Besides using secondary sources, filed mapping and survey were done. Data from two surveys were collected. First survey was conducted in two shopping centers in Zagreb (King Cross and Mercator-Zagreb) in December 2003. Second survey was conducted in two shopping centers in Ljubljana (City Park and Mercator-Šiška) in November 2005. Since general level of development of social functions is examined, gap of time does not, in our opinion, constitute an obstacle for data comparison. In Zagreb students from the Department of Geography, Faculty of Science carried out the survey, while in Ljubljana survey was carried out by students from the Department of Geography, Faculty of Arts. Questioner in Zagreb comprises 14 questions, while questioner in Ljubljana comprises 21 questions. Questioners can be divided in five groups. First group comprises general questions about age, sex, education and employment structure. Second group comprises questions about habit of coming to the shopping centre (when, how often, with whom, how). Third group of questions deals with reasons of coming to particular shopping centre and about services used during today's visit. Fourth group of questions deals with advantages and disadvantages of certain shopping centre. Last, fifth group of questions deals with habit of buying in local shops and in city centre. Since questioner from Zagreb does not comprise questions about habit of buying in city centers results from Ljubljana were compared with the result obtained by 
the survey conducted in the Ilica Street in Zagreb. Visitors were questioned when leaving shopping centers. Potential respondents were chosen by the method of systematic sampling where every fifth visitor was approached. Children younger than 8 were not considered to be active visitors and therefore were not approached. Both surveys were part of a larger research and only part of the results is presented in this paper.

\section{DEVELOPMENT OF NEW FORMS OF RETAIL IN ZAGREB}

New forms of retail comprise all forms that first appeared in the retail system during the period of transition. Therefore new forms of retail outlets are shopping centers, hypermarkets and other hybrid forms. Opening started in Zagreb in the mid - 1990s when first shopping centers in the city center were opened. First shopping center was Importanne centar opened in 1994 near the main railway station. In the year 1999, with the opening of Mercatonne in Donji Stupnik, first shopping center at the fringe of the city was opened.

Tab.1. Number of retail outlets in Zagreb

Tab.1 Broj trgovina $u$ Zagrebu

\begin{tabular}{|c|c|c|c|c|c|}
\hline Year & $\begin{array}{c}\text { No. of } \\
\text { outlets }\end{array}$ & Index & Year & $\begin{array}{c}\text { No. of } \\
\text { outlets }\end{array}$ & Index \\
\hline 1991 & 2828 & - & 1998 & 6711 & - \\
\hline 1992 & 2858 & 101,06 & 1999 & 6702 & 99,86 \\
\hline 1993 & 3013 & 105,42 & 2000 & 6615 & 98,70 \\
\hline 1994 & 2850 & 94,59 & 2001 & 6440 & 97,35 \\
\hline 1995 & 2953 & 103,61 & 2002 & 6616 & 102,73 \\
\hline 1996 & 2468 & 83,58 & 2003 & 6540 & 98,85 \\
\hline 1997 & 2407 & 97,53 & 2004 & 6374 & 97,46 \\
\hline- & - & - & 2005 & 6099 & 95,68 \\
\hline- & - & - & 2006 & 6281 & 102,98 \\
\hline
\end{tabular}

Source: Statistical Yearbook of Zagreb, selected years

Izvor: Statistički ljetopis grada Zagreba, odabrane godine

In general enlargement of floorspace is followed by the reduction in the number of outlets but that trend is more present in the sphere of goods for short term provision (groceries) (Knego, 1998). When monitoring number of outlets in Zagreb and Croatia in transition period one must distinguish a period prior to 1998 and a period after $1998 .{ }^{2}$ In table 1 number of retail outlets in Zagreb is presented. Following 1991 and 1998, there is no exceptional growth trend or diminishing in the number of outlets in relation to the initial year, the changes were periodic. This is due to a large dynamics of outlets opening and closing as a consequence of unstable economic situation in the retail sphere conditioned by the entry of foreign retail chains. An annual overview does not fully show a large dynamics of changes since numerous outlets are opened and closed within the same year. 
Martina Jakovčić, Dejan Rebernik - Comparative Analysis of Development of Retail and Shopping Centres After 1990 in Ljubljana and Zagreb

Tab. 2. New retail centres in Zagreb (March 2007)

Tab.2 Novi kupovni centri u Zagrebu (ožujak 2007.)

\begin{tabular}{|c|c|c|c|c|}
\hline Name & Type & \begin{tabular}{|c|} 
Area $\left(\mathrm{m}^{2}\right)$ \\
- estimation \\
\end{tabular} & Opening year & $\begin{array}{c}\text { No. of business } \\
\text { premises }\end{array}$ \\
\hline Importanne Centar & shopping centre & 35000 & 1994 & 250 \\
\hline Shopping centar Prečko & shopping centre & - & 1996 & 100 \\
\hline Rotonda Centar & shopping centre & 2200 & 1995 & 33 \\
\hline Importanne Galleria & shopping centre & 47000 & 1999 & 150 \\
\hline Mercatone & shopping centre & 36000 & 01.12 .1999$. & 26 \\
\hline Kaptol Centar & shopping centre & 43000 & 14.12 .2000 & 114 \\
\hline King Cross & shopping centre & 43000 & 22.09 .2002 & 94 \\
\hline Branimir Centar & shopping centre & 44000 & 2003 & 32 \\
\hline Solidum & shopping centre & 30000 & 2004 & 55 \\
\hline City Center One & shopping centre & 61000 & 2006 & 85 \\
\hline Avenue Mall & shopping centre & 80000 & \begin{tabular}{|c} 
opening Aug. \\
2007 \\
\end{tabular} & 125 \\
\hline Super Konzum $1^{*}$ & sh.c.- hypermarket & 1974 & 1995 & 4 \\
\hline Super Konzum $2^{* *}$ & sh.c.- hypermarket & 3000 & 2001 & 6 \\
\hline Mercator Zagreb & sh.c.- hypermarket & 15000 & 14.09 .2001$. & 31 \\
\hline Getro Novi Zagreb & sh.c.- hypermarket & 14000 & 14.10 .2005 . & 26 \\
\hline Vrutak & hypermarket & 2400 & 1992 & 1 \\
\hline Super Konzum Črnomerec & hypermarket & cca 2500 & 2006 & 8 \\
\hline $\begin{array}{c}\text { Super Konzum } \\
\text { Novi Zagreb }\end{array}$ & hypermarket & - & - & 2 \\
\hline Super Konzum Dubec & hypermarket & - & - & 2 \\
\hline Billa Rotor & hypermarket & 2000 & 1999 & 1 \\
\hline Billa Dubrava & hypermarket & 2000 & 1999 & 1 \\
\hline Billa Dugave & hypermarket & 2000 & 2000 & 1 \\
\hline Billa Črnomerec & hypermarket & 2000 & 2003 & 1 \\
\hline Billa Heizelova & hypermarket & 2000 & 26.10 .2006 & 1 \\
\hline Plodine & hypermarket & 3500 & 2001 & 2 \\
\hline Getro Črnomerec & hypermarket & 3350 & Nov. 2003 & 2 \\
\hline Getro Vrbani & hypermarket & 4653 & 31.10 .1998$. & 3 \\
\hline Getro Sesvete & hypermarket & 8500 & 07.11 .1994$. & 2 \\
\hline Kaufland Branimirova & hypermarket & 5186 & 04.09 .2003 & 9 \\
\hline Kaufland Dubrava & hypermarket & cca 2000 & 2005 & 9 \\
\hline Metro Sesvete & hypermarket & 7938 & 21.11 .2002 & 1 \\
\hline Metro Jankomir & hypermarket & 8400 & 06.12.2001. & 1 \\
\hline Bauhaus Jankomir & specialized hypermarket & 11000 & 12.12 .2003 & 2 \\
\hline Merkur & specialized hypermarket & 6000 & 2002 & 1 \\
\hline Pevec & specialized hypermarket & 6000 & 1998 & 2 \\
\hline Pevec Jankomir & specialized hypermarket & 8000 & Dec. 2003 & 2 \\
\hline RK Doma & specialized hypermarket & 8300 & 07.09 .2001$. & 2 \\
\hline Gramat Baumarket & specialized hypermarket & 6000 & Jun. 2000 & 1 \\
\hline Kika & specialized hypermarket & - & 2006 & 2 \\
\hline Bauhaus Žitnjak & specialized hypermarket & 8000 & 2000 & 2 \\
\hline Baumax - X & specialized hypermarket & 11300 & 04.11 .2003$. & 1 \\
\hline
\end{tabular}

* Super Konzum 1 - Ulica grada Vukovara 275

${ }^{* *}$ Super Konzum 2 - Zagrebačka avenija 108

Source: Management of shopping centres; List of major Croatian retail outlets by counties, Department of retail, Croatian Chamber of Commerce; mapping

Izvor: Podaci Uprava trgovačkih centara; Pregled najvećih hrvatskih maloprodajnih kapaciteta po županijama, Sektor za trgovinu, Hrvatska gospodarska komora, 2007; kartiranje 
Croatian retail system in the late 1990s and early 2000 is characterized by opening of large number of retail outlets with large floor space offering a mix of goods for short term provision and specialized hypermarkets. In table 2 one can see list of retail centres, year of the opening, and number of premises in centres and classification of centres. In Zagreb there are 41 retail centres. 41,4\% are hypermarkets (17), followed by shopping centres with $26,6 \%$ (11) and specialized hypermarkets with $21,9 \%$ (9). Four retail outlets can be classified ad shopping centre - hypermarket.

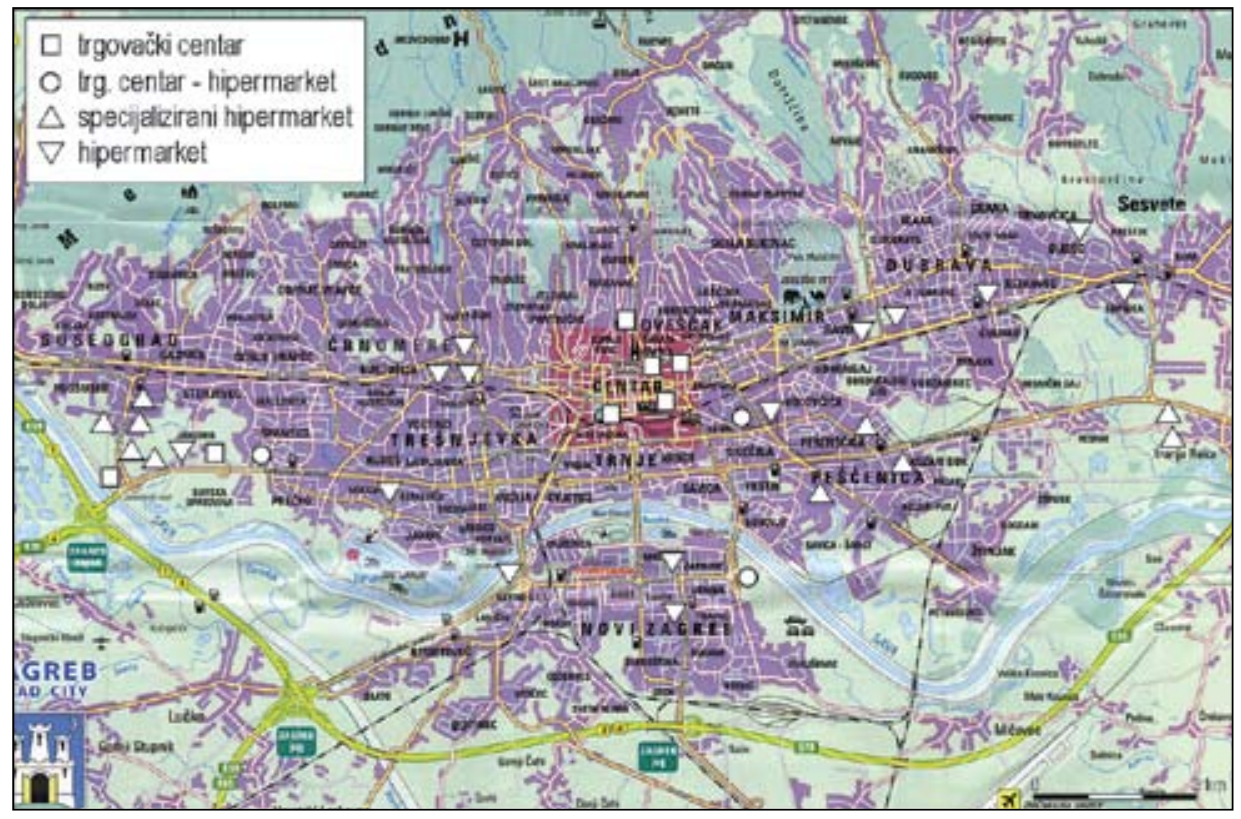

Fig. 1. Location and typology of retail centres in Zagreb

Sl.1 Lokacija i tipologija kupovnih centara u Zagrebu

Source: Mapping

Izvor: Kartiranje

After 1990s a change in the location of outlets occurred. In general one can talk about suburbanization of retail. Factors that contributed to the suburbanization of retail are unresolved property-rights relations, high rents and the non-existence of available free space in town centers and enlargement of floorspace, lower land prices, better accessibility, and available parking spaces at the fringe of the city and in suburban zones. Another set of factors that gave rise to the process of suburbanization are social factors such as: suburbanization of residential functions, changes in the lifestyle, growth of purchasing power, rise of level of automobilization etc. (Kulke 1997b; Hallsworth 1994, Gerhard 2001). In Zagreb we can distinguish four main types of retail location: (I) city centre (central business district); (II) intersection of main city avenues in the residential neighborhoods; (III) along main city avenues; (IV) near highway exits (Lukić, Jakovčić, 2004; Jakovčić, Spevec 2004; Lukić, 2002). Location of retail centres in Zagreb is shown in figure 1. Due 
to the reasons stated before in the text, in the city centre only different types of shopping centers are located while other types of retail centers such as hypermarkets, specialized hypermarkets and hypermarket-shopping centers are located in other three zones.

\section{DEVELOPMENT OF NEW FORMS OF RETAIL IN LJUBLJANA}

As in the rest of Slovenia the development of retail in the period of economic transition was very fast in Ljubljana as well. Total retail floor space grew from $150.000 \mathrm{~m}^{2}$ in 1989 to $225.000 \mathrm{~m}^{2}$ in 1999 and $335.000 \mathrm{~m}^{2}$ in 2001 . According to the study Retail in Municipality of Ljubljana in year 2002, commissioned by Urban Planning Department of Municipality of Ljubljana, total retail floor space in Ljubljana reached $453.000 \mathrm{~m}^{2}$ in March 2003 (Trgovina na drobno v Mestni občini Ljubljana v letu 2002, 44).

The factors that determined the development of retail in Ljubljana are similar to those valid for the rest of Slovenia, but some specific factors are characteristic as well. Among common factors we can list economic transition from planned to market economy, privatization, development of entrepreneurship, foreign direct investment, underdevelopment of service sector in socialist economy, increased social polarization and increased purchase power of population. Specific factors that influenced fast development of retail in Ljubljana are: higher purchase power then in the rest of the country, which is generally reflected in increased consumption of durable goods, good accessibility of Ljubljana, which directly influences the enlargement of gravitation area of retail in Ljubljana and development of tourism and growth of the number of tourists visiting Ljubljana.

Tab. 3. Retail centres in Ljubljana (March 2006)

Tab.3 Novi kupovni centri u Ljubljani (ožujak 2006.)

\begin{tabular}{|c|c|c|c|c|}
\hline Name & Type & $\begin{array}{c}\text { Area }\left(\mathbf{m}^{2} \mathbf{)}-\right. \\
\text { estimation }\end{array}$ & $\begin{array}{c}\text { Opening } \\
\text { year }\end{array}$ & $\begin{array}{c}\text { No. of } \\
\text { business } \\
\text { premises }\end{array}$ \\
\hline BTC & Shopping centre & 70.000 & 1993 & 400 \\
\hline Rudnik & Shopping centre & 50.000 & 2000 & 25 \\
\hline City Park & Shopping centre & 37.500 & 2002 & 90 \\
\hline Leclerc & Shopping c.-hypermarket & 10.000 & 2000 & 22 \\
\hline Mercator Center & Shopping c.-hypermarket & 9.000 & 1998 & 35 \\
\hline Interspar Vič & Shopping c.-hypermarket & 10.000 & 1997 & 25 \\
\hline Lesnina Brdo & Specialized hypermarket & 12.000 & 1999 & 3 \\
\hline Bauhaus & Specialized hypermarket & 15.000 & 1997 & 1 \\
\hline Harvey Norman & Specialized hypermarket & 15.000 & 2002 & 1 \\
\hline Merkur Vič & Specialized hypermarket & 5.000 & 1998 & 1 \\
\hline Diskont Črnuče & Hypermarket & 2.000 & 1998 & 1 \\
\hline Hofer & Hypermarket & 2.000 & 2005 & 1 \\
\hline
\end{tabular}

Source : Trgovina na drobno v Mestni občini Ljubljana v letu 2002, 2003, Field mapping March 2006 Izvor: Trgovina na drobno v Mestni občini Ljubljana v letu 2002, 2003, kartiranje ožujak 2006 
Due to lack of available locations, poor accessibility with private cars and very high prices of land no shopping centers developed in the centre of Ljubljana. The growth of retail in Ljubljana is mainly the consequence of creation and development of suburban shopping centers in the last 15 years. The beginning of suburban shopping centers in Ljubljana and Slovenia can be observed in the year 1993 when the first suburban shopping centre BTC was opened. In the following years the development of suburban shopping centers was very fast and has been accompanied by gradual decline of retail in city centers. In Ljubljana only $18 \%$ of all sales floor remained in city centre, whereas $45 \%$ of sales floor was located in suburban shopping centers.

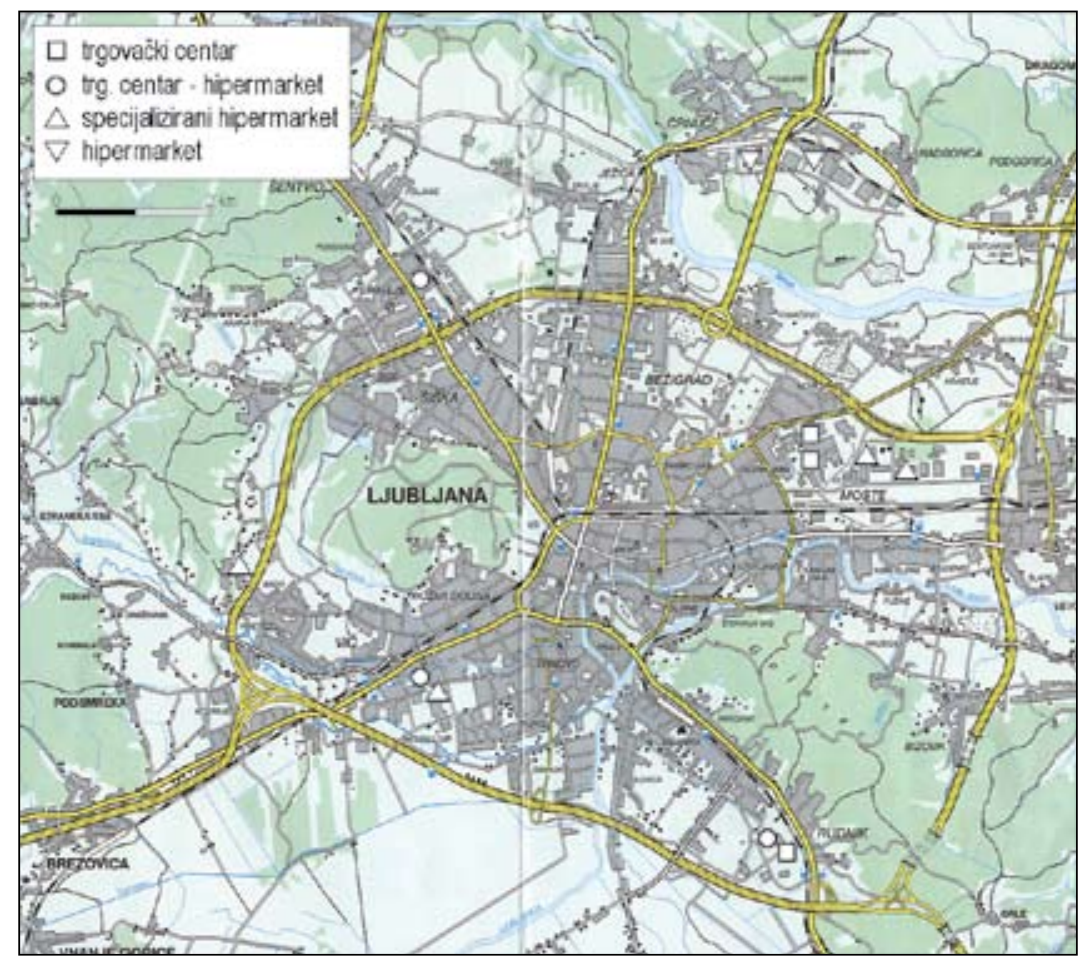

Fig. 2. Location and typology of retail centres in Ljubljana Sl. 2 Lokacija i tipologija kupovnih centara u Ljubljani

Source: Mapping

Izvor: Kartiranje

Location and spatial distribution of shopping centers in Ljubljana is in the first place determined by good accessibility with cars. Shopping centers BTC, City Park, Rudnik and Brdo are all located close to highway exits, which gives them excellent accessibility from the whole urban region. Shopping centers Mercator and Vič are located at main entrance avenues from northwest and southwest. Their accessibility from the rest of urban region is relatively poor but on the other hand they are located close to densely populated residential areas. Although good accessibility with public transport is characteristic for shopping 
centers BTC, City Park, Interspar and Mercator a vast majority of visitors use their cars to reach these shopping centers. Another factor that determined the spatial distribution of shopping centers in Ljubljana is availability of space. Shopping centers developed on two types of locations: as redevelopment of abandoned industrial or other derelict urban areas or as new development in areas designed as commercial in planning documents. As a consequence of many derelict urban areas in the city the first type of locations is more frequent.

\section{COMPARISON OF SPATIAL DISTRIBUTION, FUNCTIONAL STRUCTURE AND SOCIAL FUNCTIONS OF SHOPPING CENTRES IN LJUBLJANA AND ZAGREB}

In spite of many similarities in development of retail in all transitional countries there are some significant differences in spatial distribution, functional structure and social functions of shopping centers in Ljubljana and Zagreb. The main difference regarding the spatial distribution of shopping centers in Ljubljana and Zagreb is lack of shopping centers in central parts of Ljubljana. All shopping centers in Ljubljana are located in the suburbs, most of them close to highway ring exits, which gives them excellent accessibility from the whole urban region. On the other hand, shopping centers in Zagreb are located on four types of locations: city centre, the intersections of main urban avenues in large residential quarters, location along main urban avenues and close to highway exits on the outskirts of urban area (Lukić, A. 2002, Lukić A., Jakovčić, M. 2004, Jakovčić, Spevec, 2004). Five out of eleven shopping centers in Zagreb are located in the city centre. This pronounced dissimilarity in spatial distribution can be explained by several factors.

In central part of Ljubljana there are no available and large enough locations, which would enable the development of large shopping centers. In Zagreb derelict urban areas in city centre were redeveloped as shopping centers, which is not the case of Ljubljana. Shopping centers in the city centre of Zagreb are thus partly located at the former industrial plants (i.e. Centar Kaptol located at the place of former footwear industry Astra). Considering their main functions, in Zagreb one can differ among different types of shopping centers depending on their location. Shopping centers in the city centre, besides having retail, have entertainment, business and residential functions, while centers located close to highway ring still have dominant retail function. In Ljubljana, in all shopping centers except BTC, retail remains the main activity and reason of visit (Rebernik, Jakovčić, 2006). BTC shopping centre, situated close to highway ring and about 4 kilometers from the city centre, developed a wide variety of entertainment, catering, recreation and cultural functions, which were traditionally located in the city centre. In this way BTC shopping centre, which has more sales floor then the central part of Ljubljana, and is acquiring typical CBD functions, is becoming the "second" centre of the city. The problem of decline of retail and "commercial blight" in city centre is thus much more pronounced in Ljubljana than in Zagreb.

With the development of road network the accessibility of suburban locations close to highway ring is much better than the accessibility of city center. The city centre is 
better accessible by public transport, but the use of public transport is decreasing very fast. In Ljubljana its share in urban traffic flows decreased to only about $10 \%$. A survey conducted in 5 largest shopping centers in Ljubljana in November 2005 has shown that cars are dominant means of transport to the shopping centre $(79.3 \%)$, followed by walking $(11.1 \%)$. The highest, but still relatively low percentage of visitors who use public transport is characteristic for shopping centers BTC and City Park (14 \% and $13.2 \%)$. The use of public transport in Zagreb is higher. In Zagreb public transportation includes buses, trams and urban railway system. In the year 2004, number of passengers who used public transportation (tram and buses combined) was 253000 passengers. In this way the accessibility of central parts of Zagreb is better than in Ljubljana, which is influencing the development of CBD shopping centers in Zagreb. 58.5\% of visitors interviewed in Centar Kaptol came to the center by public transportation or on foot (Lukić, 2002). On the other hand all shopping centers in Zagreb located at the fringe of the city or near main urban avenues have large parking lots since majority of visitors use cars as the prime means of transportation (up to $96,5 \%$ in King Cross). The highest percentage of visitors who use public transport or walks to the shopping centre is characteristic for retail centre Mercator-Zagreb (12,9\% and 14,15\% respectively) and can be explained by its location just opposite the road of a large residential area and near the tram station.

Next section of the paper gives comparison of functions of retail centers in Zagreb and Ljubljana. The main goal is to determine the level of development of social functions. Another goal is to determine similarities and differences in the function of retail centers in Zagreb and Ljubljana. For that purpose comparison of data collected by surveys done in City Park and Mercator-Šiška in Ljubljana and King Cross and Mercator-Zagreb in Zagreb will be given.

City Park and King Cross are examples of two centers located near highway rings, while Mercator-Zagreb and Mercator-Šiška are located along the main avenues near densely populated residential areas. According to number of premises, type of goods and services and an estimation of extension of gravitation area City Park and King Cross can be classified as regional retail and service centers and Mercator-Šiška and Mercator-Zagreb can be considered urban retail center. (Rebernik, Jakovčić, 2006). This thesis can be sustained by data gathered in survey which indicates that in King Cross and City Park 68,3\% and 70\% of visitors questioned live in Ljubljana, while in Mercator-Zagreb and Mercator-Šška this percentage is $93,4 \%$ and $84,9 \%$ respectively. For King Cross and City Park gravitation area is the whole urban region and all parts of the city. On the other hand most of visitors questioned in Mercator-Zagreb and Mercator-Šiška live in nearby residential areas. In this way it is confirmed that gravitation area of urban shopping centers is limited to a part of urban area (Rebernik, Jakovčić, 2006). In Mercator-Zagreb 23,6\% of visitors questioned lives in the same residential area where the centre is located but specific is a fact that large number of the visitors comes to the centre because they work in the vicinity or because their employees have contract with the restaurant in the centre so they spend their lunch-breaks there.

In order to determine social functions of retail centers visitors were asked about duration of staying in the centre, services used, reasons for visiting particular center etc. 
In both City Park and King Cross the highest percentage of visitors stayed between one and two hours (37,9\% and 46,3\% respectively), while in Mercator-Šiška and MercatorZagreb visits shorter than one hour prevailed (51\% and 61,2\%). In Mercator-Šiška and Mercator-Zagreb less than 1,5\% of visitors spend more than 3 hours in the centre, while in City Park and King Cross that number was relatively higher (7,8\% and 4,6\%).

Share of visitors who visited some form of catering service is lowest in MercatorZagreb (28,2\%), followed by King Cross (30\%), Mercator-Šiška (30,4\%) and City Park $(40,1 \%)$. Using catering service is positively connected with the length of stay. This can be confirmed by the fact that only $27 \%$ of visitors who stayed in City Park for less than an hour visited coffee bar or restaurant while that share is much higher $(76,9 \%)$ among visitors who stayed for more than 3 hours. Difference is even bigger in King Cross and amounts $9 \%$ for visitors who stayed less than an hour as opposed to $70 \%$ who stayed more than three hours.

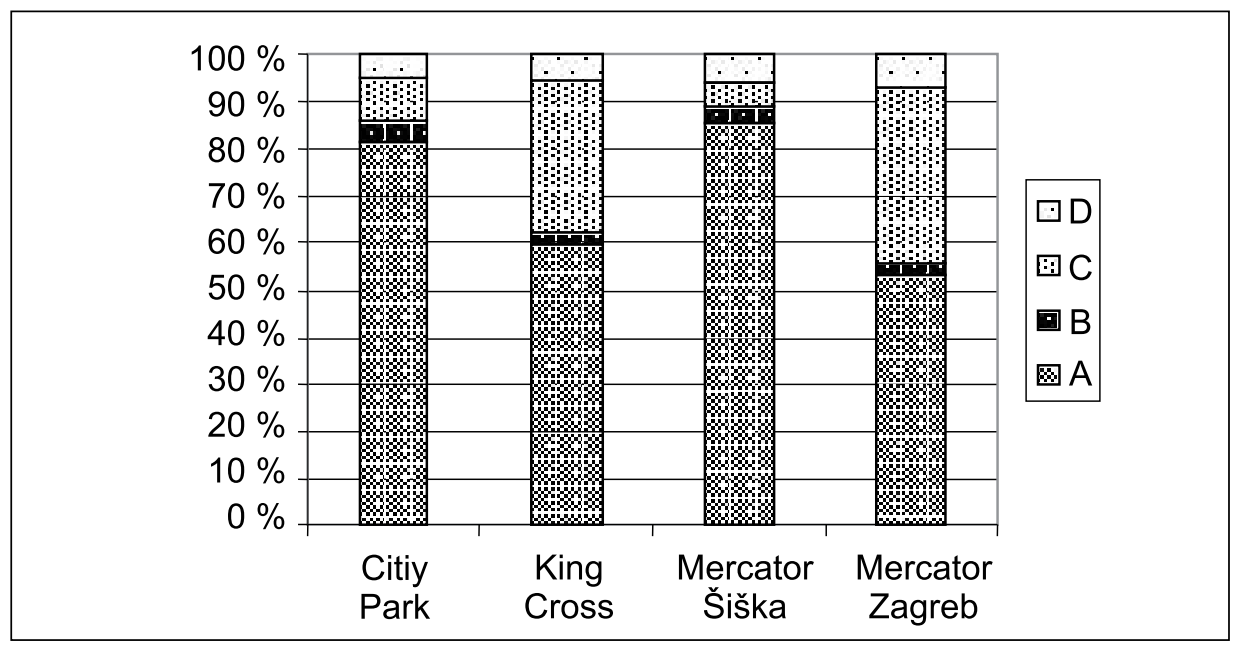

A-purchase; $\mathrm{B}$ - socializing with friends; $\mathrm{C}$ - leisure, recreation; $\mathrm{D}$ - using catering and other service

A-kupovina; $B$-druženjes prijateljima; $C$-zabava, provođenje slobodnog vremena;

$D$ - ugostiteljske i ostale usluge

Fig. 3. Main reason for visiting retail centers

Sl.3 Glavni razlozi dolaska u kupovne centre

Source: survey

Izvor: anketiranje

In all retail centers, regardless of duration of staying, the main reason for coming was purchase. Contrary to retail centers in Ljubljana in retail centers in Zagreb important reason for visiting centers is leisure or recreation. Spending free time in shopping centers is not a specific of shopping centers in Zagreb. ${ }^{3}$ But yet still we can not talk of "tribalism" in a way that we cannot denote group of people who makes their own subculture hanging out and spending their free time in a shopping mall (Hudson, 2005). 
Social function of retail centers can also be evaluated through inquiring the companionship during the visit of the shopping centre. Data differs greatly between centers but in general it can be said that larger percentage of visitors who came to center alone was noted in Mercator-Šiška and Mercator-Zagreb than to two other centers. In the case of Mercator-Šiška a large percentage $(43,4 \%)$ can be explained by the fact that the majority of visitors come to shop and other reasons for visiting the centre is merely noted. But this reason is not valid in the case of Mercator-Zagreb. In the case of Mercator-Zagreb percentage of people who came to the center alone was higher in the morning $(64 \%)$ than in the afternoon (53\%). In the morning share of older visitors is also higher than in the afternoon. $40 \%$ of visitors interviewed in the morning was more than 60 years old and almost $57 \%$ percent of all visitors who came to Mercator-Zagreb and who are more than 60 years old came to the center alone.

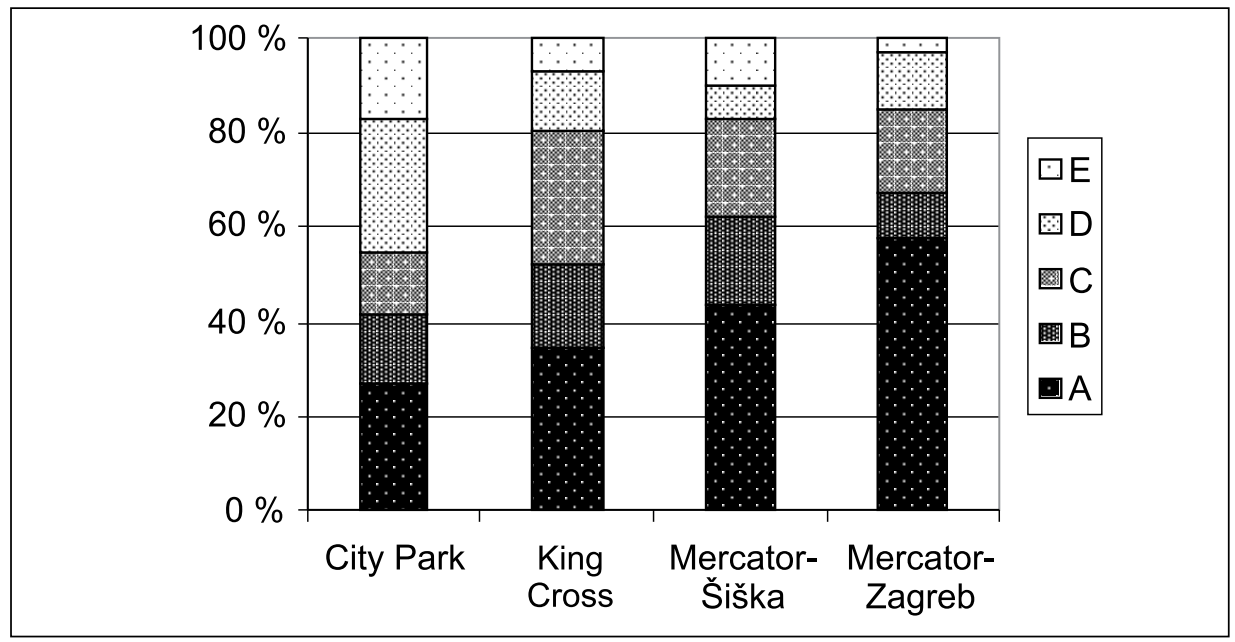

A - alone; B - spouse; C - family; D- friends; E - boyfriend/girlfriend

A-sam/sama; $B$-s bračnim partnerom/partnericom; $C$-s obitelji; $D$-s prijateljima;

E-s dečkom / djevojkom

Fig. 4. With whom do visitors come to retail centers?

Sl.4 S kim ste posjetili centar?

Source: survey

Izvor: anketiranje

Modern shopping centers are often advertised as places of family shopping. Even if one does not come to the mall with his or her family their purchase is largely influenced by their family since family is the most important factor in forming one's identity. Despite that we must differ between "shopping as a family" and "family shopping" (Miller et al., 1998) Percentage of visitors who came to the centers with their families is higher in Zagreb than in Ljubljana but is still not as high as it might be expected.

The last section of questions deals with connection between buying in local shops and town centers and buying in shopping centers. Among the shoppers questioned in the 
survey in shopping centers, the percentage of those who still buy their daily groceries in small local shops, is still high in all centers. The percentage is the smallest in MercatorZagreb which can be correlated to the fact that this particular centre is located in highly populated residential area and that $27 \%$ of visitors questioned comes to Mercator-Zagreb several times a week, another $23 \%$ two to three times a week and $6,3 \%$ comes to the centre on a daily bases. This shopping centre has thus a function of local shopping centre as well. In general we can say that the percentage of people who buy daily groceries in local shops is still quite high, ranging from 53,3\% of shoppers questioned in Mercator-Zagreb to $78,7 \%$ in City Park. Looking at the frequency of visits to the shopping centers and habit of buying in local shops it can be concluded that there are no obvious connections and that opening of shopping centers does not affect local shops. However that is not true since value of purchased goods is much higher in shopping centers than in local shops. (Rebernik, Jakovčić, 2006) The share of local shopping centers in Ljubljana is evaluated to only $37 \%$ and is continuing to decrease (Trgovina na drobno v Mestni občini Ljubljanav letu 2002, 2003). Also as a survey conducted in the centre of Zagreb indicates $14,3 \%$ of managers or owners of food stores in Ilica street think that opening of shopping centers bears a negative consequence on their business.

\section{CONCLUSION}

On the basis of comparative analysis of development of retail in Ljubljana and Zagreb we can conclude that in spite of many similarities in development of retail in all transitional countries there are some significant differences in spatial distribution, functional structure and social functions of shopping centers in Ljubljana and Zagreb. The main difference in spatial distribution of new shopping centres in Ljubljana and Zagreb is the fact that there are no shopping centres in the central part of Ljubljana whereas 5 centrally located shopping centers developed in Zagreb. This is a consequence of different role of public transport and consequently different accessibility of central and suburban parts of Ljubljana and Zagreb, different use of derelict urban areas in both cities and different social functions of new shopping centers. CBD shopping centers in Zagreb developed strong social functions (places for social contacts, entertainment) whereas in Ljubljana only the largest shopping centre BTC developed social functions. In this way new shopping centres in Zagreb contribute to strengthening the attractiveness and vitality of city centre. In Ljubljana, on the other hand, the problem of decline of retail and "commercial blight" in parts of city center and local shopping centers can be observed. Observed differences are in part a consequence of different size of both cities and their urban regions (pop. 265.000 in the inner city and 500.000 in urban region of Ljubljana and pop. 700.000 in the inner city and 1.000.000 in urban region of Zagreb) and different structure of both urban regions.

Comparison of large suburban shopping centers in both cities confirms their similar location, structure and social functions. Suburban shopping centers maintain retail as main function and reason of visit. The majority of visitors use private cars to reach them. Shopping centres located close to densely populated residential areas acquired a function of local and neighborhood shopping centre, whereas shopping centers located close to highway exits developed as regional shopping centers with large gravitation areas. 


\section{NOTES}

1. In general, Kulke distinguishes two basic periods in retail transition: (1) there is privatization, but there are no major changes in either the structure of supply and demand or locations; (2) with penetration of the market by foreign retail chains, processes of retail concentration begin, and there are changes in location. (Kulke 1997a)

2. Until 1998, retail was monitored statistically as wholesale and retail. Since 1998, apart for wholesale and retail, mediation in wholesale has been included within the category of retail distribution, as have the repair of motor vehicles and motorcycles, objects for personal usage, and households.

3. For instance in United States shopping is second most important free time activity, following watching TV. (Lukić, 2002)

\section{REFERENCES}

Anić, I.D. 1999: Internacionalizacija europske maloprodaje i Hrvatska, Ekonomski pregled 50, 5-6, $583-612$.

Anić, I.D., Vouk, R. 2000: Razvojni problemi hrvatske maloprodaje u uvjetima internacionalizacije europske maloprodaje, Hrvatska gospodarska revija, 49, 1, 40-52.

Distributivna trgovina u 2000., Statističko izvješće 1158, Državni zavod za statistiku, Zagreb

Drozg, V., 2001: Nakupovalna središča v Sloveniji. Geografski vestnik 73, 1, 9- 21.

Gerhard, U., 2001: Shopping and Leisure: New patterns of consumer behavior in Canada and Germany, Die Erde 132, $205-220$.

Hallsworth, A.G., 1994: Decentralization of Retailing in Britain: The Breaking of the Third Wave, The Profesional Geographer 46, 3, 296 - 307.

Jakovčić, M., Spevec, D., 2004. Trgovački centri u Zagrebu. Hrvatski geografski glasnik, 66, 1, 47-66.

Knego, N. 1998: Tendencija u razvoju suvremene europske maloprodaje, Ekonomska misao i praksa, 7, 1, 85-103.

Kulke, E. 1997a: Aspekte des Transformationsprozesses im Einzelhandel Ostmitteleuropas, Die Erde, 128, 173-189.

Kulke, E. 1997b, Effects of the economic transformation process on the structure and locations of retailing in East Germany, Journal of Retailing and Consumer Services 4, 1, 49-55.

Lukić A. i Jakovčić M., 2004: Location and functions of hypermarkets and shopping centres in Zagreb, Dela 22, $39-54$.

Lukić, A., 2002. Socijalne funkcije trgovačko - poslovnog središta: primjer Centra Kaptol u Zagrebu. Hrvatski geografski glasnik, 64. Zagreb. 73 - 94

Miller, D. et al. 1998: Shopping, place and identity, Routledge, London

Pak, M., 2002: Funkcijska zgradba Ljubljane. Geografija Ljubljane. Oddelek za geografijo Filozofske fakultete v Ljubljani. 131-148.

Pak, M., 2004: Specifični elementi v funkcijski zgradbi Ljubljane, Dela 22. 27-38.

Pregled najvećih hrvatskih maloprodajnih kapaciteta po županijama, Sektor za trgovinu, Hrvatska gospodarska komora, 2007.

Pütz, R. 1997: New Business Formation and Internationalisation: Aspects of the Transformation of Polish Retail Trade. Wroclaw, a case study, Die Erde, 128, 235-249 
Martina Jakovčić, Dejan Rebernik - Comparative Analysis of Development of Retail and Shopping Centres After 1990 in Ljubljana and Zagreb

Rebernik, D., 1992: Členitev Ljubljane na mestne četrti. Diplomska naloga. Oddelek za geografijo Filozofske fakultete v Ljubljani.

Rebernik, D., Jakovčić, M. 2006: Development of retail and shopping centres in Ljubljana, Dela, 26, 5-26.

Rezultati raziskovanj 733 - Prodajne zmogljivosti v trgovini na drobno 1999: Statistični urad Republike Slovenije, Ljubljana

Rezultati raziskovanj 773 - Prodajne zmogljivosti v trgovini na drobno 2001, Statistični urad Republike Slovenije, Ljubljana

Rezultati raziskovanj 803 - Letni pregled trgovine 2002, Statistični urad republike Slovenije, Ljubljana.

Sikos, T.T., Hoffmann, M. 2005, Typology of shopping centres in Budapest, J. Selye University, Research Institute, Komárno

Segetlija, Z., Lamza-Maronić. M. 1997. Trgovina na malo u Republici Hrvatskoj i potrebe njene internacionalizacije, Tržište 9, 12, 219-229.

Statistički ljetopis Grada Zagreba 2005: Odjel za statistiku, Gradski zavod za prostorno uređenje, Grad Zagreb

Statistički ljetopis Grada Zagreba 2001: Odjel za statistiku, Gradski zavod za prostorno uređenje, Grad Zagreb

Standl, H. 1998: Der postsozialistische Transformationsprozess in grossstadtischen Einzelhandel Ostmittel und Osteuropas, Europa Regional 3, 2-15.

Stare, F. 2004. Velika nakupovalna središča na obrobju Ljubljane proti majhnim trgovinam v središču mesta. Geografski vestnik 76-1. Ljubljana. 23-36.

Sykorova, I., Sykora, L. 1999, Prague Metropolitan Area, ULI Market Profiles1998: Europe, Urban Land Institute, Washington

Trgovina na drobno v Mestni občini Ljubljana v letu 2002, MOL-Oddelek za urbanizem, Ljubljana, 2003

Usmerjanje razvoja trgovine na drobno v prostoru mestne občine Ljubljana. MOL-Oddelek za urbanizem, Ljubljana, 2001

http:// www.gfk.si/4_2_lclank.php?cid=1166 : Raziskava slovenska trgovina, GKK - GRAL_ ITEO, 2007, critirano : 29.3.2007

\title{
SAŽETAK
}

\section{Komparativna analiza razvoja trgovine i kupovnih centara u Ljubljani i Zagrebu nakon 1990. godine}

\author{
Martina Jakovčić, Dejan Rebernik
}

Početkom 1990-ih, kao i u ostalim državama Srednje i Istočne Europe i u Sloveniji i Hrvatskoj započinje proces ekonomske tranzicije i prijelaza s centralno-planskog na tržišno gospodarstvo. Trgovina je bila samo jedna od djelatnosti koja započinje s procesom tranzicije. Tranzicija trgovine obuhvaća: pojavu novih tipova prodajnih prostora, promjenu lokacije trgovine u gradu, promjenu veličine prodajnih prostora, promjenu u strukturi proizvoda te promjenu vlasničkih odnosa. Jedan 
od procesa koji su obilježili proces tranzicije je internacionalizacija trgovine. Faktori koji su potakli ulazak stranih trgovačkih lanaca i gradnju prodajnih objekata velikih površina su: slaba konkurentnost domaćih trgovaca, niske cijene zemljišta i radne snage, niža razina kontrole i nejasni zakonski okviri koji omogućuju gradnju centara velikih površina te porast kupovne moći. Internacionalizacija trgovine u Hrvatskoj započinje relativno kasno u odnosu na ostale tranzicijske države. Najvažniji razlozi „kašnjenja“ internacionalizacije su nestabilne političke i ekonomske prilike (izazvane ratom) te nesređena legislatura. U Sloveniji je proces internacionalizacije započeo već 1991. otvaranjem hipermarketa Spar.

Pojava trgovačkih centara kao novog oblika trgovine odvijala se gotovo istovremeno. Prvi trgovački centar u Ljubljani bio je BTC otvoren 1993. Prvi trgovački centar u Zagrebu bio je Importanne centar otvoren 1994. Nakon 1990-ih dolazi do promjena u lokaciji trgovine. I Zagreb i Ljubljanu karakterizira proces suburbanizacije trgovine. Pri tome je suburbanizacija trgovine počela u Ljubljani znatno ranije. Već od otvaranja prvog trgovačkog centra1993. javlja se tendencija lociranja trgovačkih i ostalih kupovnih centara na rubovima grada i u blizini stambenih zona. U Zagrebu je proces suburbanizacije kasnio te započinje tek 1999. otvaranjem prvog suburbanog trgovačkog centra Mercatonne. No istovremeno otvaraju se trgovački centri u središtu grada te se danas od 11 centara njih 5 nalazi u središtu grada. Za razliku od Zagreba u Ljubljani nema trgovačkih centara u središtu grada. Razlog tome je nedostatak slobodnog prostora, slaba dostupnost osobnim automobilima i visoke cijene zemljišta. Uslijed razvoja suburbanih centara u Ljubljani došlo je smanjenja obujma trgovine u središtu grada te središte Ljubljane u određenoj mjeri gubi svoju tradicionalnu trgovinsku funkciju.

Osim razlika u lokaciji trgovačkih centara između Zagreba i Ljubljane razlike postoje i u razvijenosti socijalnih funkcija. Prema rezultatima anketiranja ekonomska funkcija je još uvijek dominantna funkcija u svim trgovačkim centrima te je glavni razlog dolaska u kupovni centar kupovina. No trgovački centri u Zagrebu imaju razvijenije socijalne funkcije. Posebice se to odnosi na centre u središtu grada koji uz mjesta kupovine postaju i mjesta zabave i provođenja slobodnog vremena te mjesta socijalizacije. Na taj način trgovački centri preuzimaju ulogu javnih gradskih prostora. U Ljubljani jedino trgovački centar BTC ima razvijene socijalne funkcije dok je u ostalim centrima dominantna ekonomska funkcija. I u Ljubljani i Zagrebu većina posjetitelja $\mathrm{u}$ trgovačke centre dolazi osobnim automobilom. Također $\mathrm{u}$ oba grada trgovački centri locirani u blizini stambenih naselja imaju gravitacijsko područje i funkcije lokalnog centra i centra susjedstva dok suburbani centri imaju veće gravitacijsko područje i brojnije i raznovrsnije funkcije te ulaze u skupinu regionalnih trgovačkih centara.

Received (Primljeno): 2007 - $09-17$

Accepted (Prihvaćeno): 2008 - $05-28$

dr.sc. Martina Jakovčić, assistant

Department of Geography, Faculty of Science

Maurulićev trg 19, Zagreb, Croatia

e-mail:mjakovci@geog.pmf.hr

dr.sc. Dejan Rebernik, assistant professor

Department of Geography, Faculty of Arts

Aškerčeva 2, Ljubljana, Slovenia

e-mail: dejan.rebernik@guest.arnes.si 